\title{
تحسين المشهد الحفريا ومعالجة التشوه البمريا للاحياءالقديمة داخل المدن دراسة حالة المدينة العربية
}

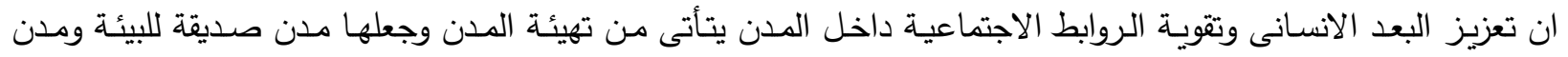

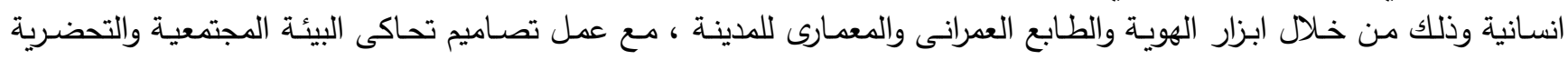

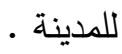

يتتاول البحث موضوع التشوه البصري للمشهد الحضري داخل الاحياء القديمة للمدن والذي اثر سلبا على البيئة الحضرية, وهو البها

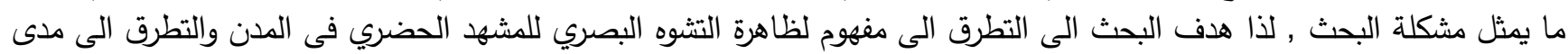

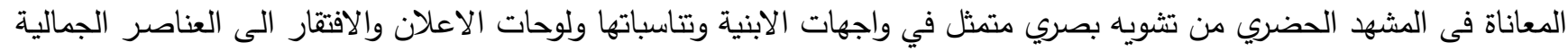

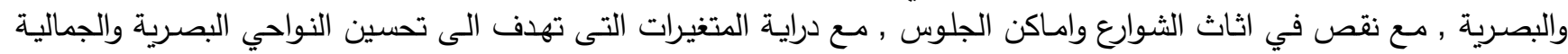

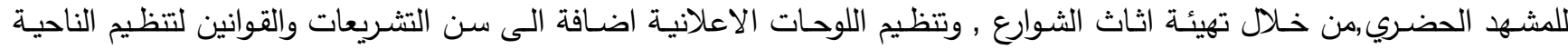

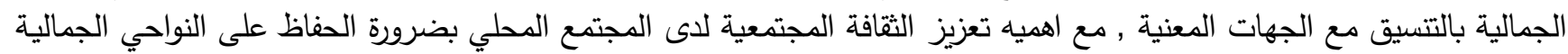

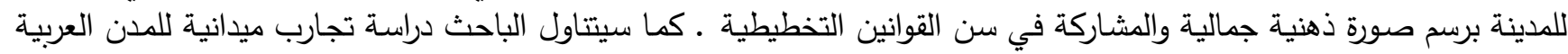

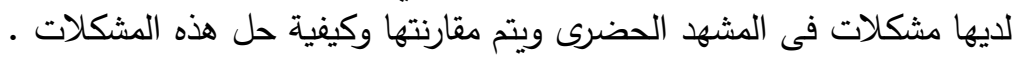

\section{الكلمات الدالة : الاحياء القديمة - التشوه البمركا - المشهد الحفركا - المجتمع المحلى}

تتعرض : المدن وبـالأخص فـى الاحياء القديمة منها لتغييرات متلاحقة نتيجة التطور السريع في مختلف النواحي العمرانيـة

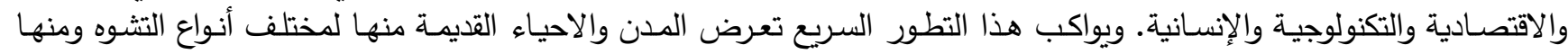

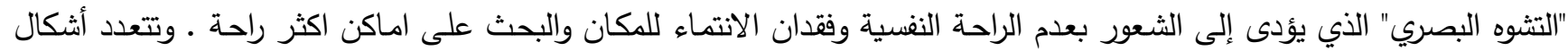

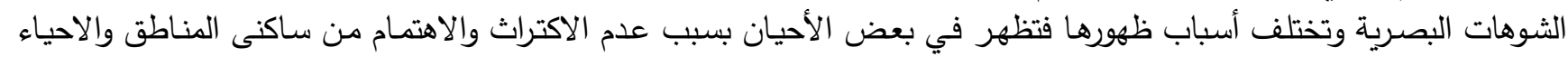

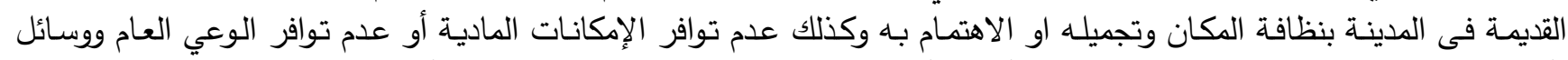

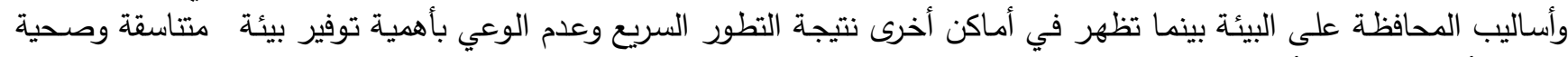

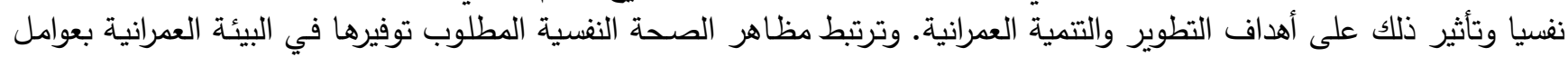

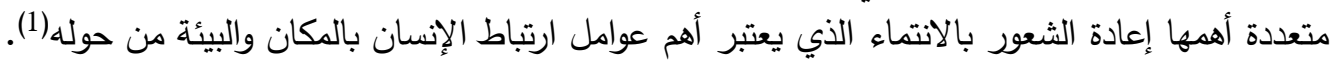

المشكلة البحثية : ظهور تشوهات بصرية داخل المدن وخصوصـا الاحياء القديمة منها تحتاج الى مشاريع لتحسين المشهر البصرى لها ، وعدم وجود وعي باساليب المحافظة على البيئة ادى بدوره الى ظهور هذه الته المشكلة

فرضية البحث : يفترض الباحث عدة فرضيات للبحث :

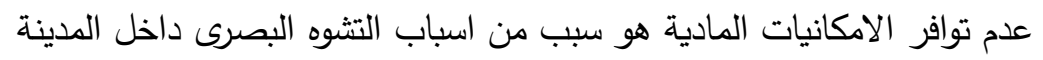

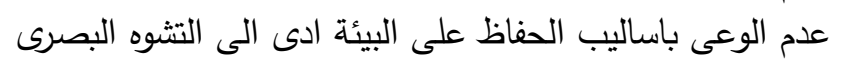
• • • • • • • •

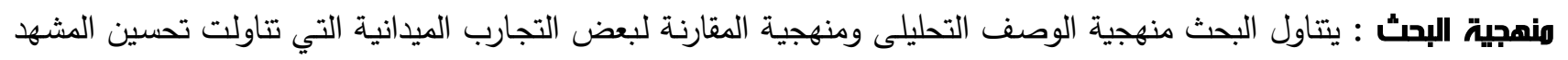
البصرى داخل مدنها .

اهداف البحث : يهدف هذا البحث إلى دراسة مظاهر العمران داخل المدن وخصوصا المناطق والاحياء القديمة منها وتحديد

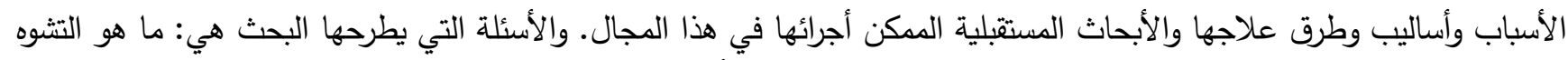

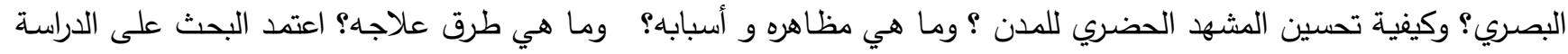

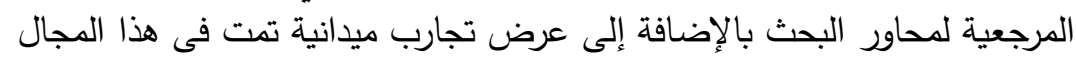
التشوه وتحسين المشهد البمريا - الإنسان والبيئة

( ${ }^{1}$ ) Kevin Lynch and Malcolm Rivkin: A Walk Around the Block. In Environmental Psychology, People and Their Environment by Harold Proshansky, William Ittelson and Leanne Rivlin. Holt, Rinehart and Winston, New York, Chicago, 


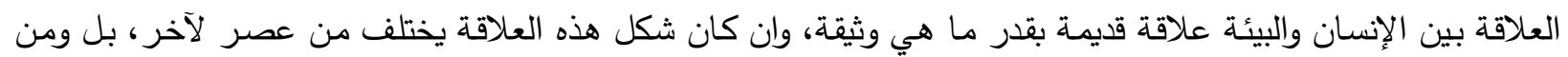

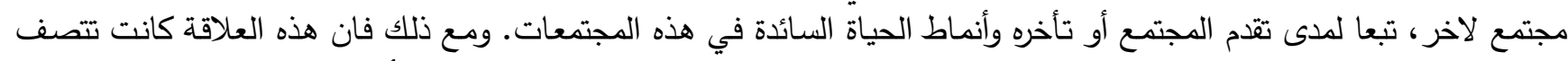

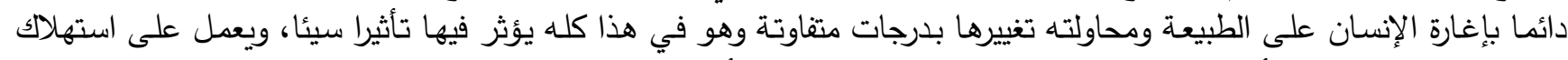

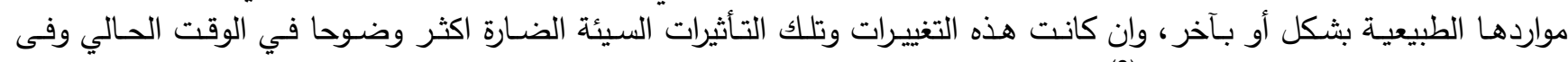

المجتمعات المتقدمة تكنولوجيا بالذات (2).

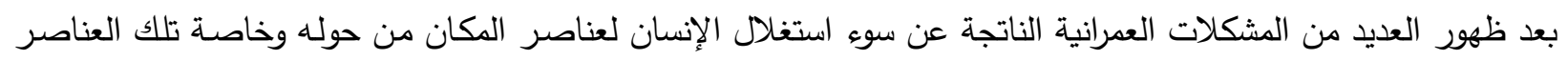

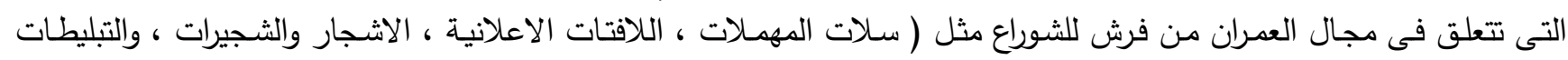

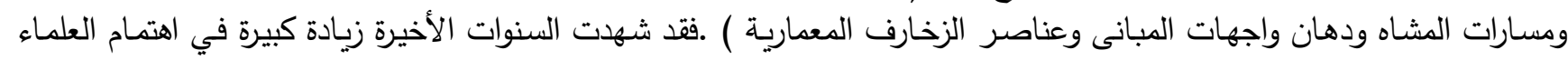

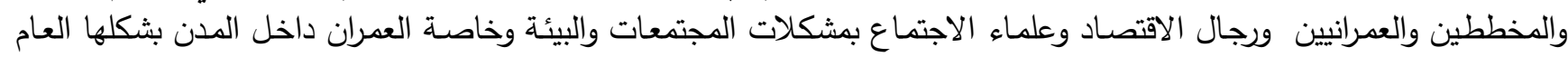

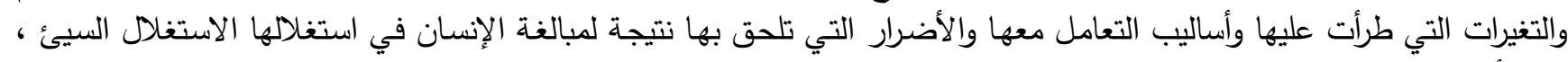

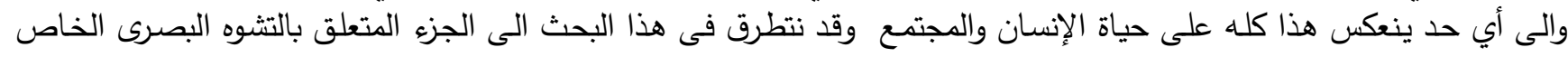
بالعمران.

\section{البيئة بمعناها العام : بان.}

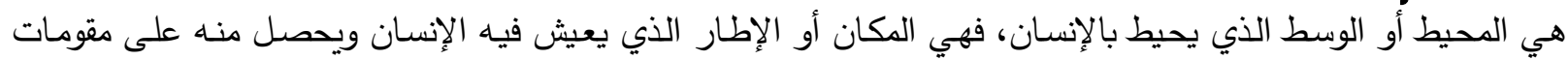

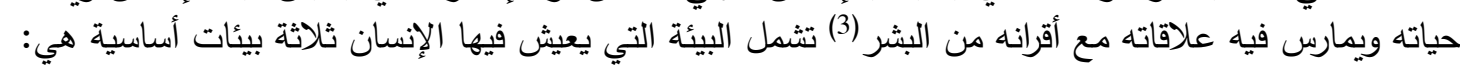

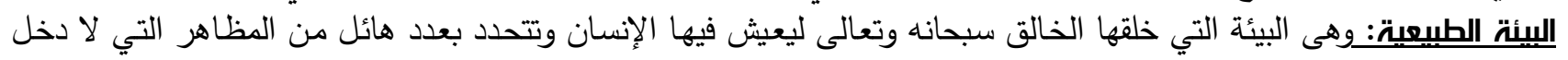

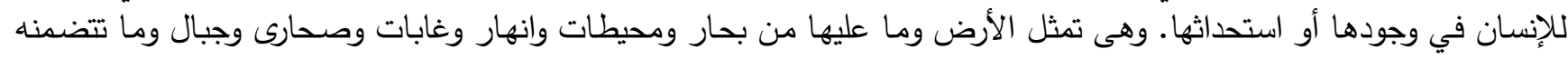

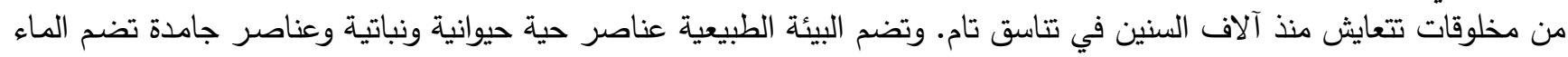

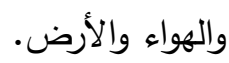
البـالبيئة العمرانية: وهى البيئة البئة العمرانية التي تضم المساكن والمباني والمنشآت في القرى والمدن الصغيرة والكبيرة والتجمعات العمرانية

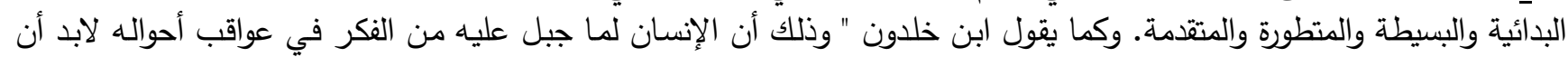

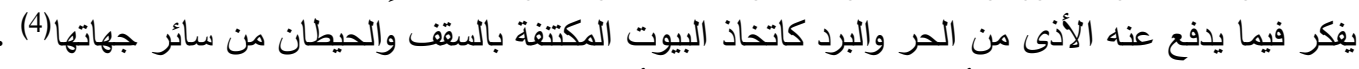

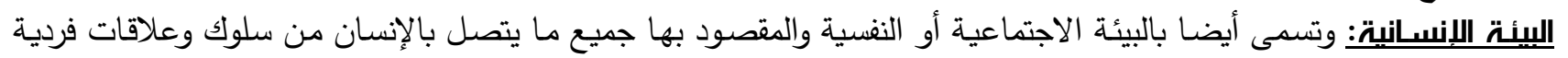

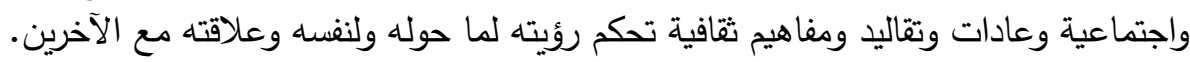

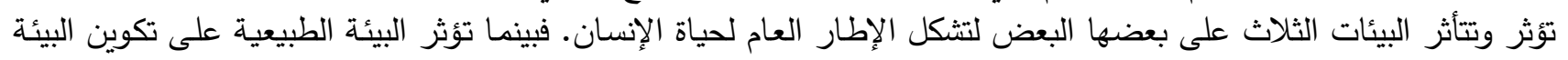

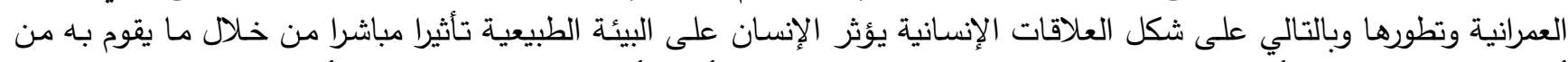

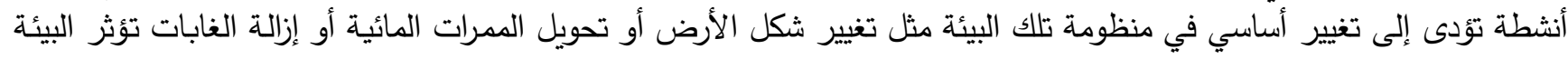

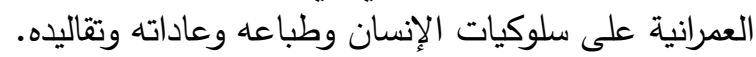

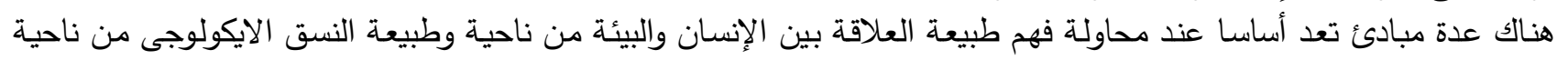
أخرى(5) ومن هذه المبادئ: تعقد العلاقة بين الإنسان والبيئة ويزيد من هذا التعقد تعرض هذه العلاقات دائما للتغير والتعديل و التحوير نتيجة للتقدم الثقافي والتكنولوجى الذي يحرزه المجتمع. • " لإني وانكول التغيرات التي يحدثها الإنسان في البيئة الطبيعية لا يمكن فهمها فهما صحيحا الا في ضوء العلاقة القوية التي تقوم بين الإنسان والمجتمع والبيئة. الإنسان جزء من النسق الايكولوجى وانه لا يوجد ويعيش بعيدا ومنعزلا عن الأنساق الايكولوجية بحيث يؤثر فيها من الخارج دون أن يتأثر بها أو يتفاعل معها.

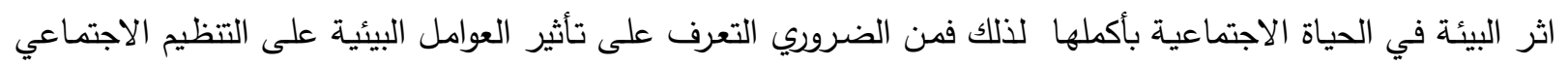
وبالتالي على البناء الاجتماعي الكلى.

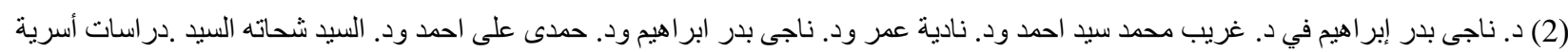

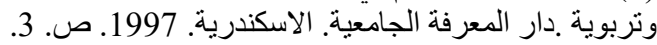

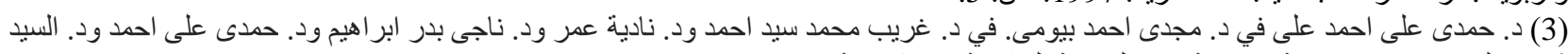

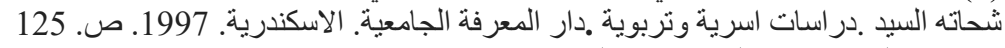

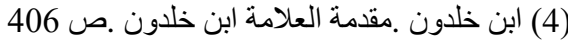

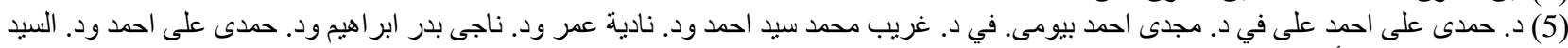

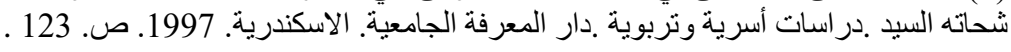


التلوث البيئي:اصبح التلوث البيئى والتثوه البصرى داخل المدن مشكلة من المشكلات التي حظيت فجأة باهتمامات الناس في

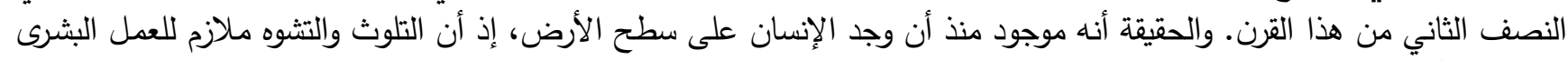

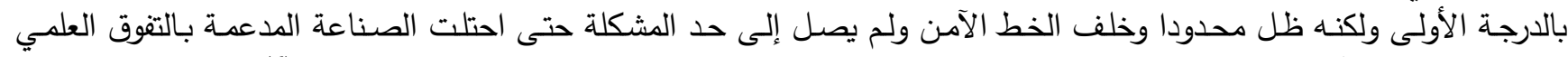

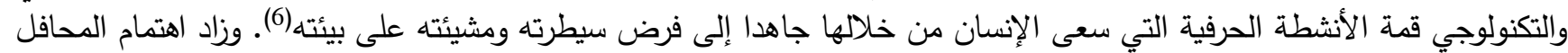

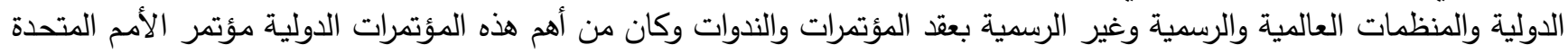

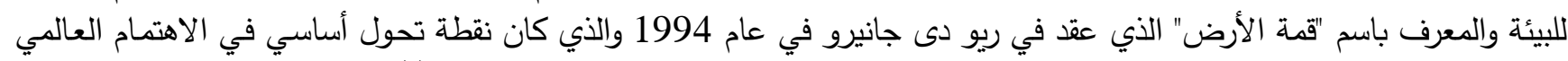

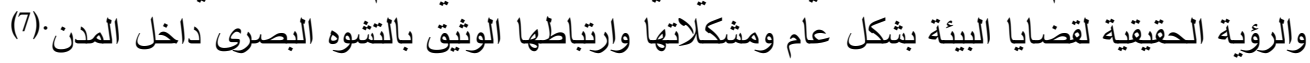

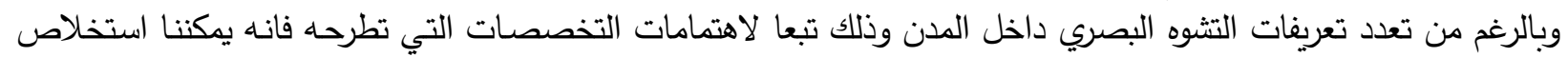

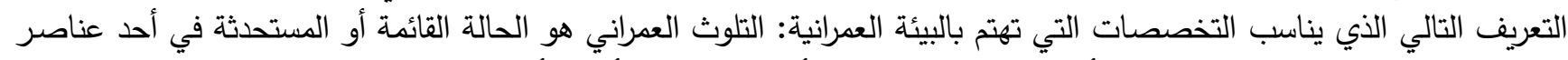

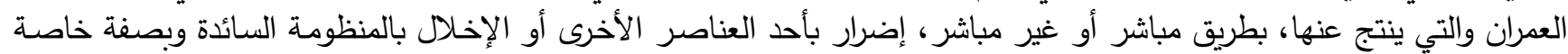

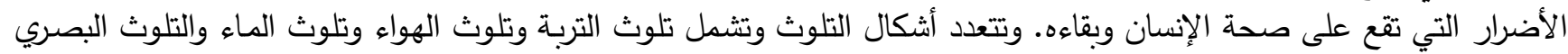

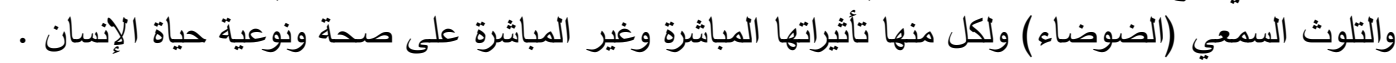

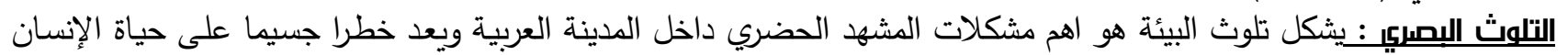

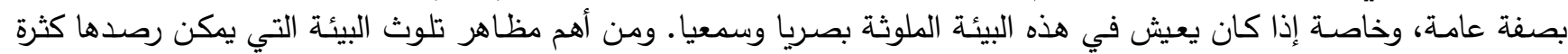

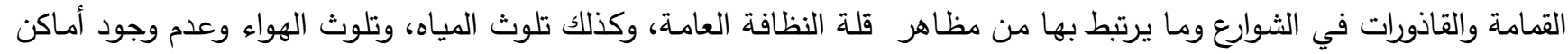

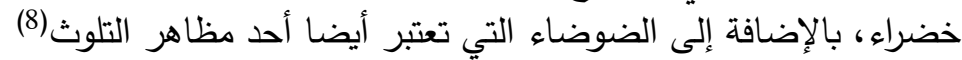

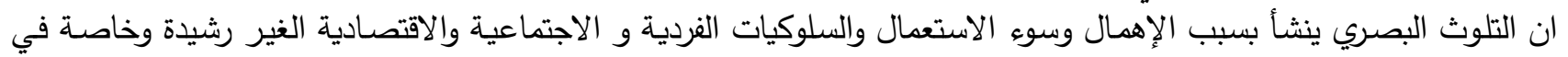

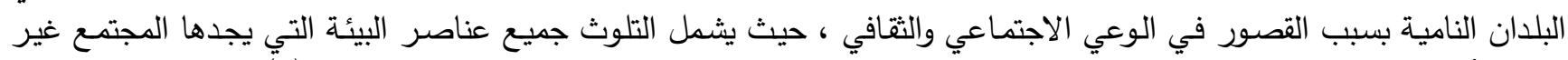

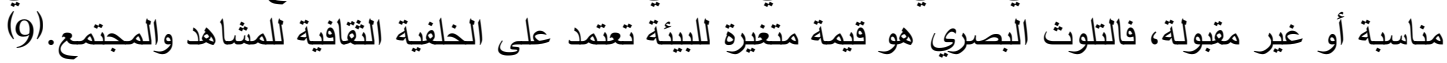

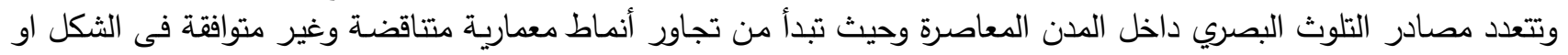

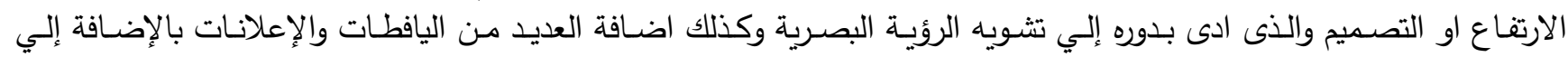

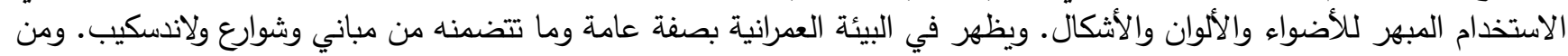

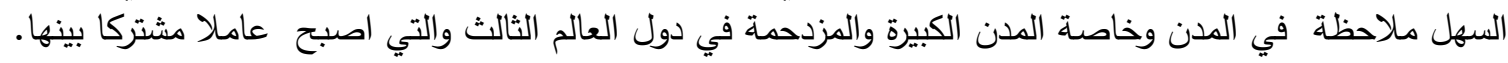
يمكن تحديد ملامح التشوه البصري في النقاط التالية: تنافر الثكل والنسب واللون والحركة. كل ما ينقص من النظافة والسلامة والأصالة النالة

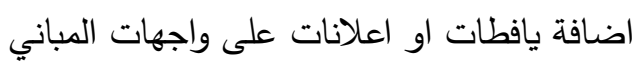
كل ما ينقص من النظافة والسلامة والأصالة. وجود عنصر ينافى المعالم البيئية ويبدو دخيلا على البالئية البئة. كل ما يخد الذوق العام سواء بالرسم أو الإثارة أو الكلام. كل العوامل التي تقلل من تكامل الإحساس الجام الجمالي للبيئة.

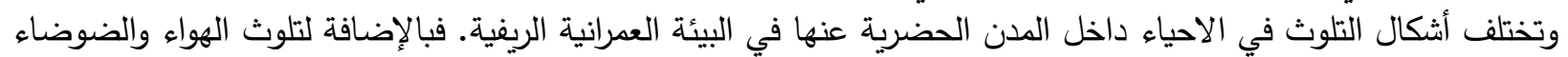

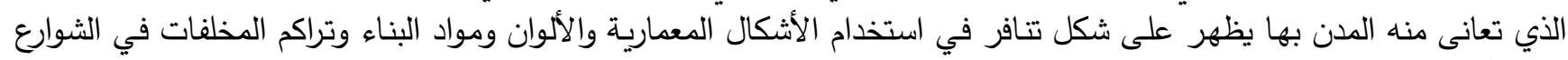

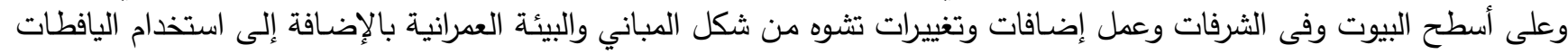

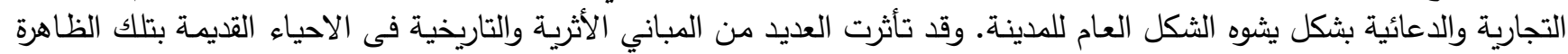

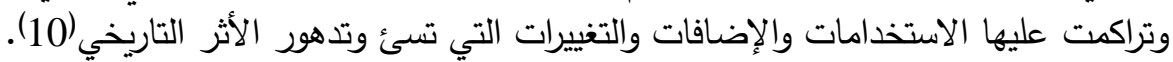

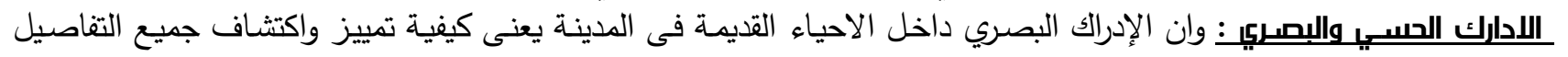

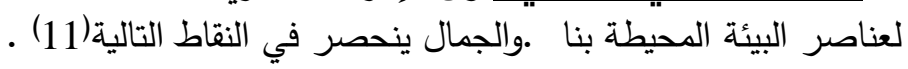
الجمال الفكري الوظيفي: وهو يعنى بمدى وضئوح المضمون الوظيفي للعمل المعماري أو الفني ومدى ملاءمته للثكل الناتج.

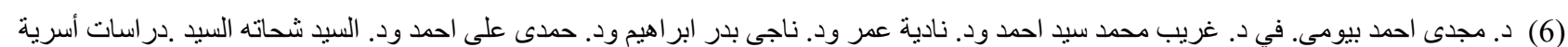
وتربوية .دار المعرفة الجامعية. الاسكندرية. دئ 1997. ص. ص. 92

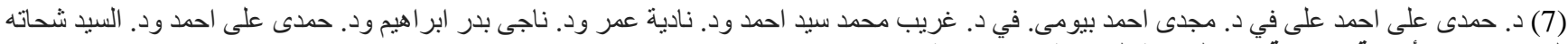

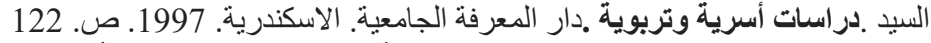

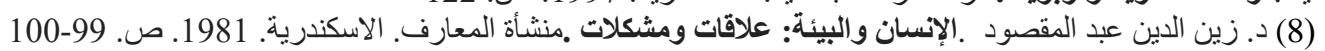

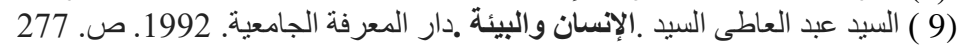

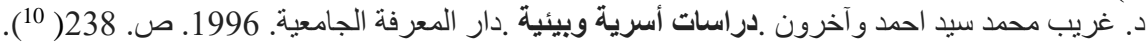


الجمال الفكري التجريدي: وهو يعنى بالجماليات العامة الناشئة عن التكوينات المعمارية أو الفنية وتثكيلاتها.

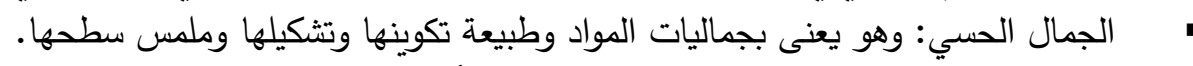

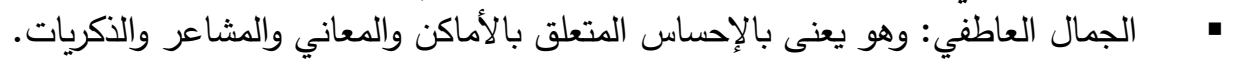

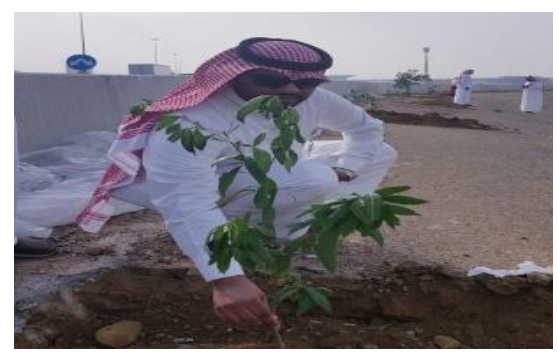

\section{تطبيقيات بعض المدن العربية ( تحسين المشهد البمريا )}

\section{المهلكة العربية السعودية : مكت المكرهة}

فيى الملتقى الثقافي بامـارة منطقـة مكـة المكرمـة دشـن فرع وزارة البيئـة والميـاه

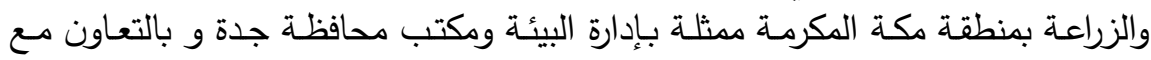

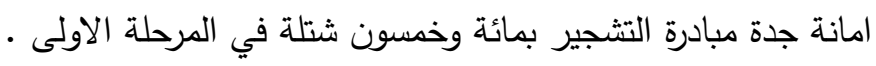

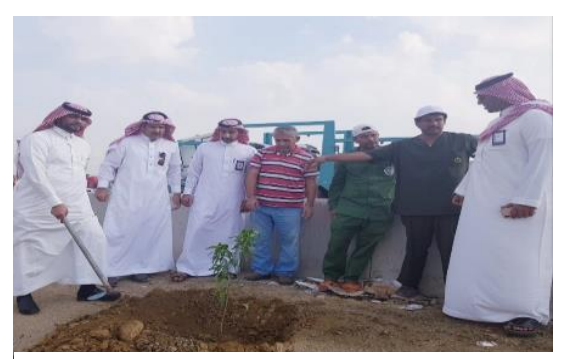

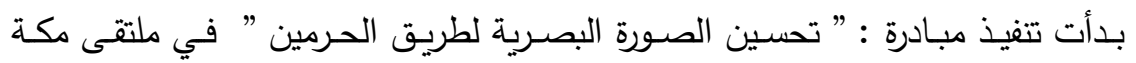

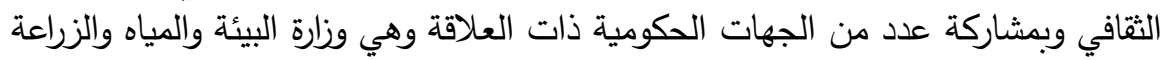

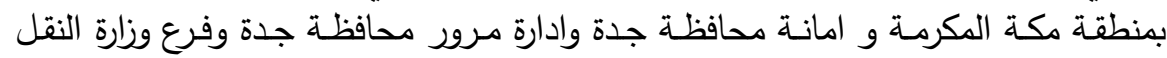

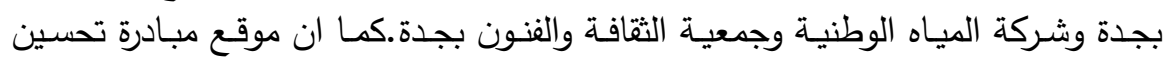
المشهد البصري لطريق الحرمين يقع في المنطقة الواقعة بين كوبري فلسطين وحتى محطة

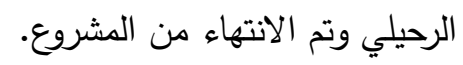

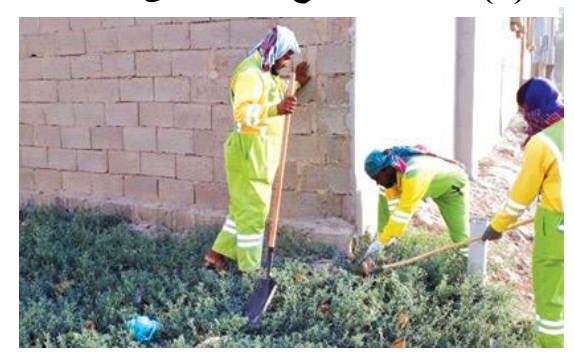

(2) صورة توضح ازالة الحشائش الطفيلية

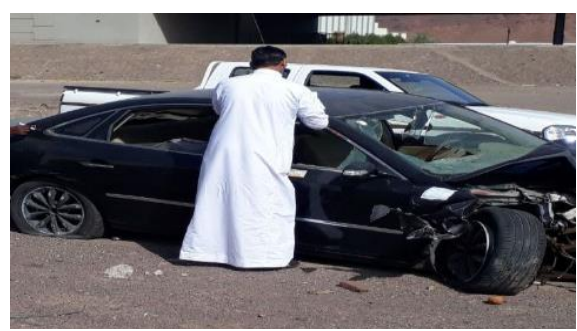

(3) صورة توضح رصد السيارات

المتهالكة تمهيدا لاز التها

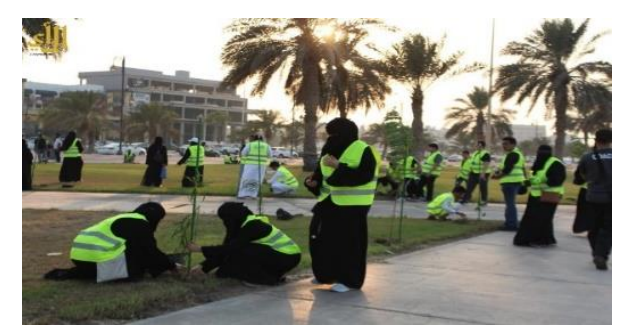

(4) صورة توضح مشاركة المرأة فى المقئ تحسين المشهر الحضرى
(1) صورة توضح العمل على زراعة

كمـا تم عمل مبادرة معالجـة التلوث البصـري اطلقتها أمانـة العاصمة المقدسـة وهى

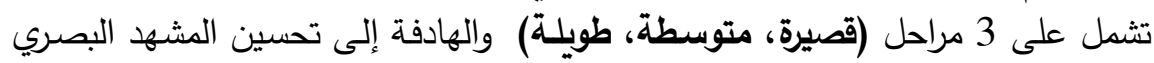

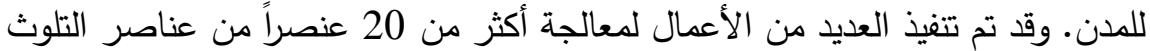

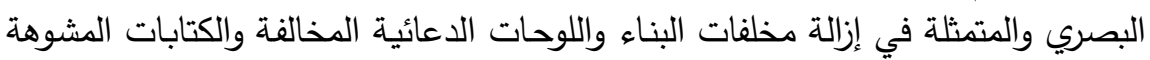

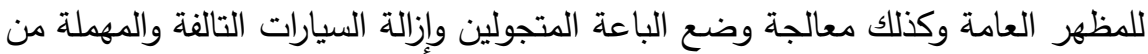

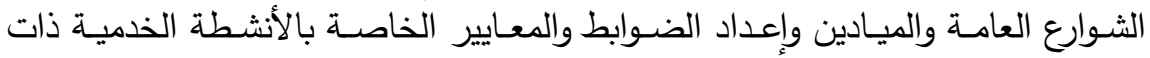

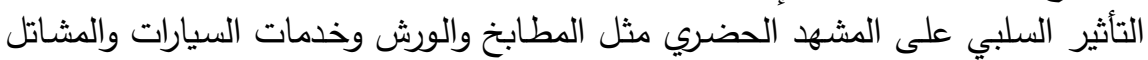

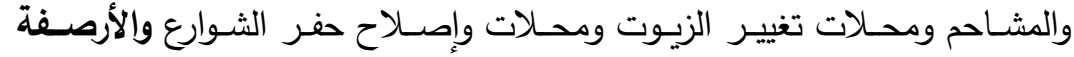

المتهالكة وإصلاح أعمدة الإنارة وازالة الحشائش الطفيلية كما توضحه الصورة رقم (1)

\section{تحربة المدينة المنورة :}

عالجت أمانة منطقة المدينة المنورة 1431 مخالفة تشوه بصري ، والقائمين باعمال

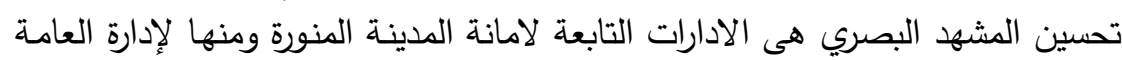

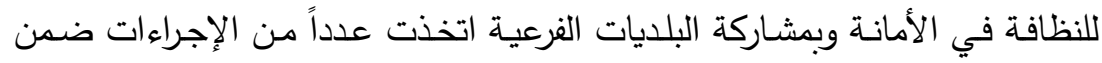

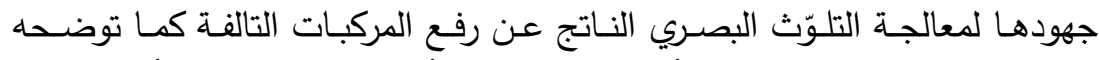

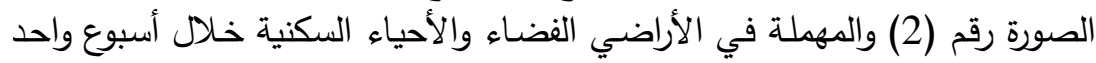
وأضاف إن الإجراءات شملت رفع وحجز 382 مركبة مخالفة، ومتابعة وإزالة 517 والعاء لوحة دعائية مخالفة، ومتابعة وإزالة 532 كتابة على الجدران مشوهة للمنظر العام.

\section{المنطقة الشرقية / المهلكة العربية السعودية}

من ضمن دراسات أمانة المنطقة الثرقية لتحسين المشهر البصري الاعـلان

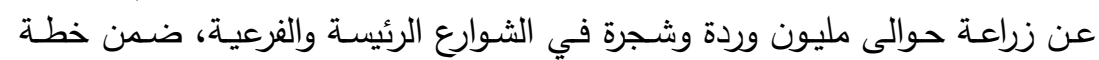

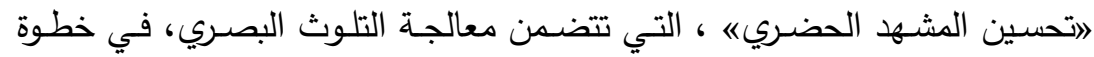

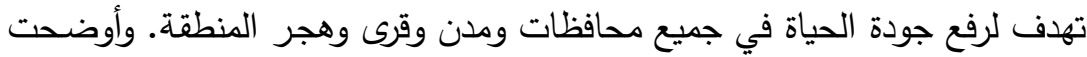

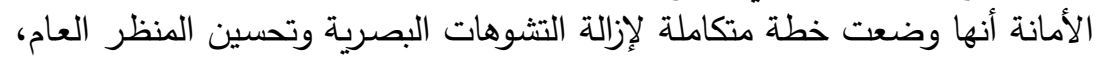
من خلال برنامج "جودة الحياةه،الذي يعتبر تحسين المشهد البصري ألحالة الحد عناصرها، ووصفت النتائج التي تحققت بالإيجابية 


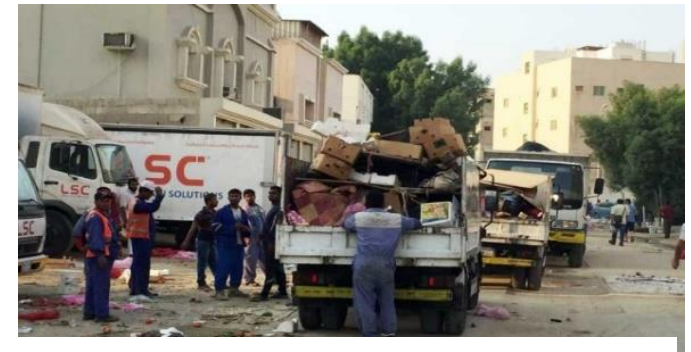

(5) صورة توضح ازالة المخلفات داخل الاحياء

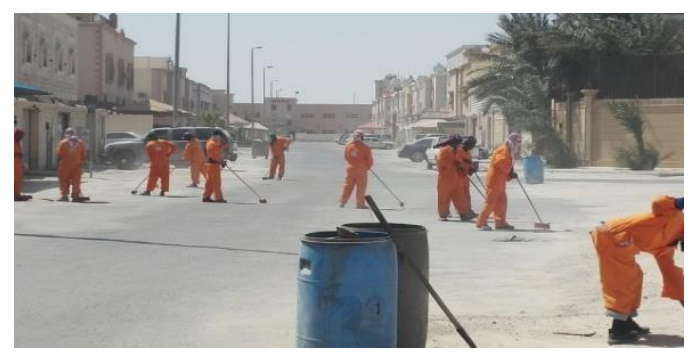

(6) صورة توضح تنظيف الثوارع بعد ازالة المخلفات

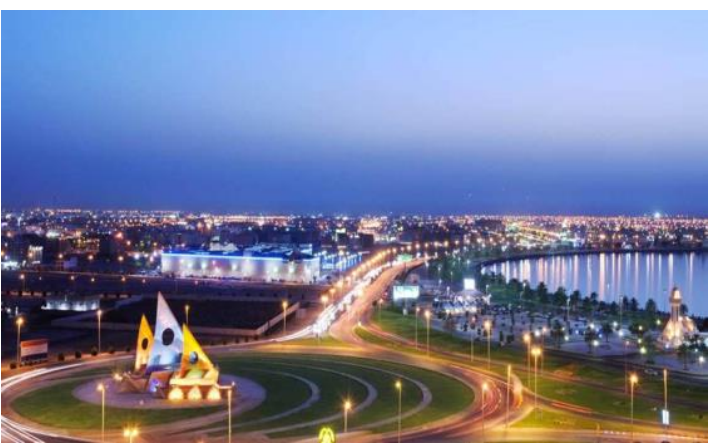

(6) صورة توضح منظر عام لمدينة الامام

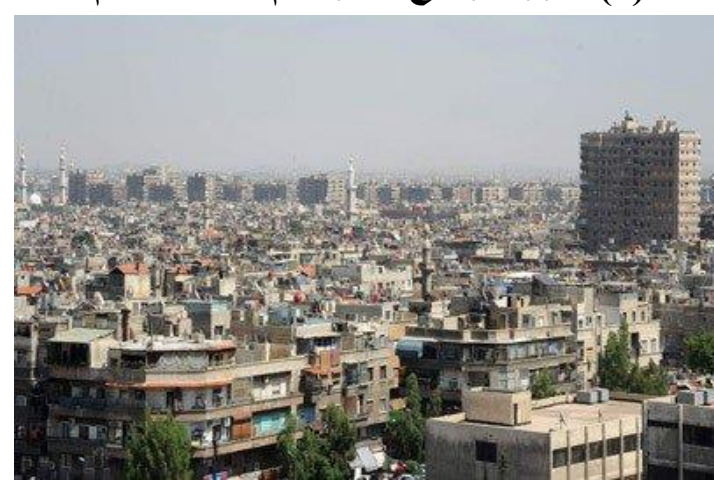

(7) صورة توضح منظر عام لمدينة دمشق

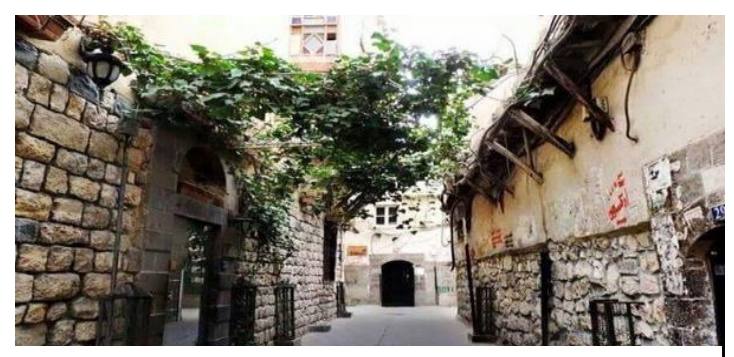

(7) صورة توضح احد الحارات التى تحتاج الى

ترميم
وقد تم إزالة مخلفات البناء والهدم ونواتج الحفر والنفايات ذات الحجم الكبير

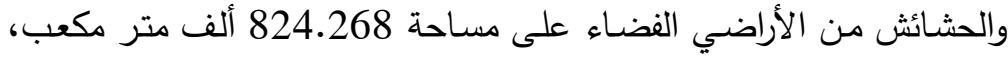
فيما بلغ عدد أرقام المباني ولوحات الأبن مسميات الشوارع التي تم إصلاحها 545

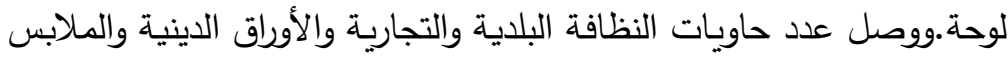

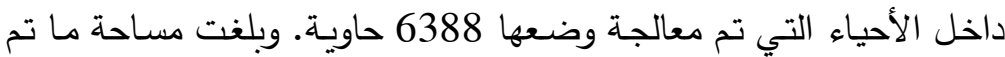

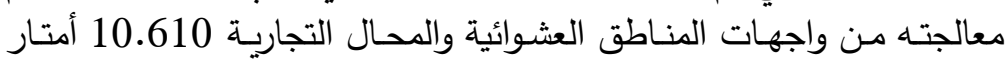

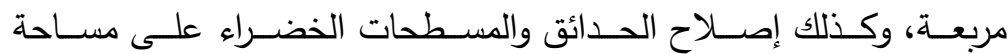

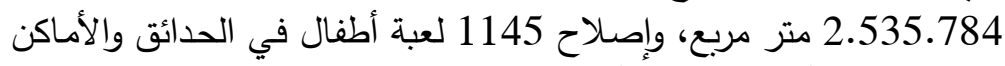

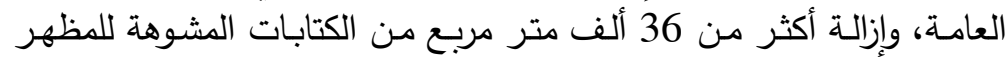

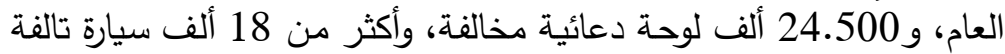

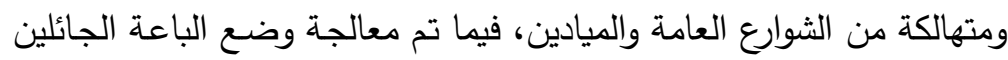

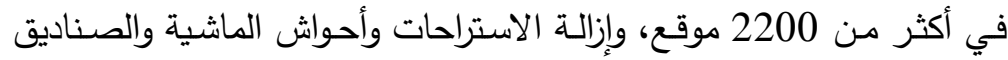

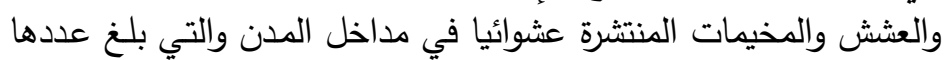

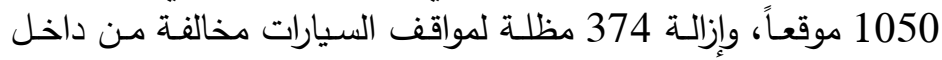

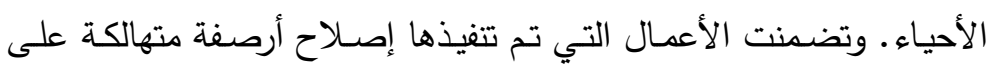

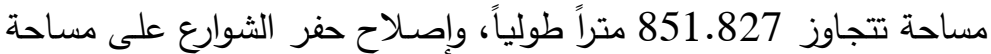

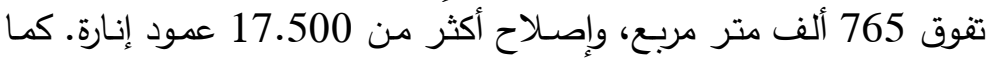

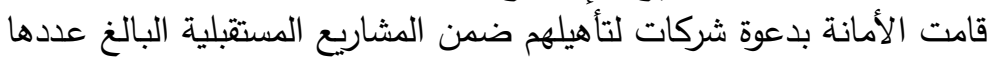

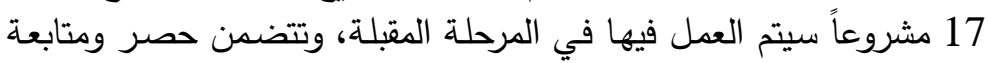

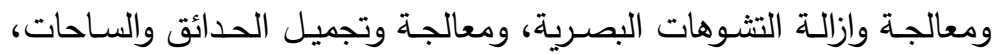
وكذلك معالجة وإصلاح الحفر في الطرق والثوالتهارع.

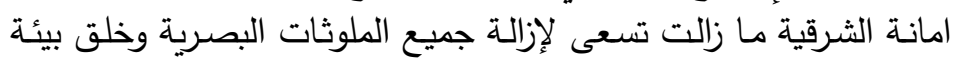

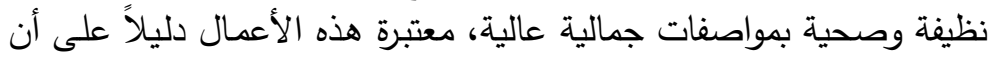

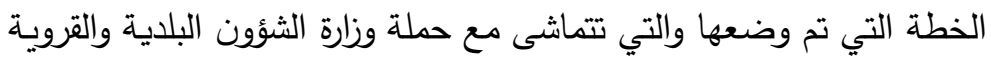

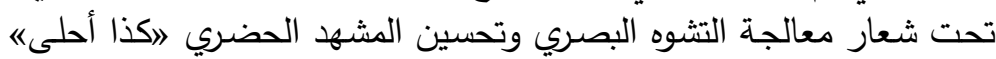

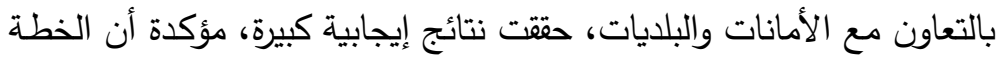

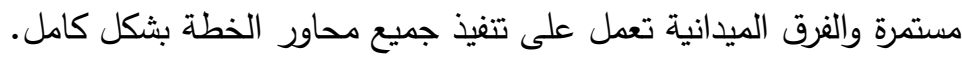

\section{مدينة دمشق / سوريا}

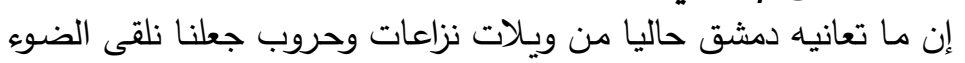

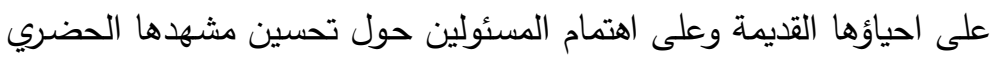

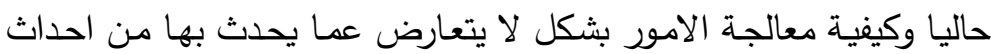

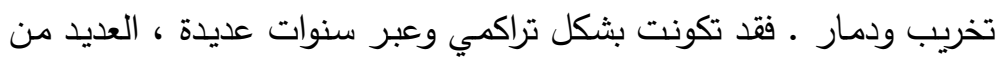

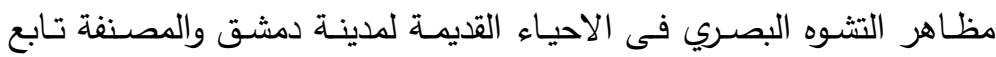

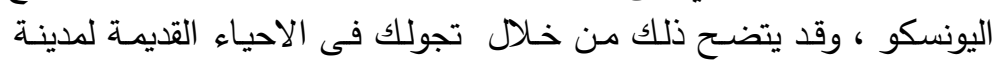

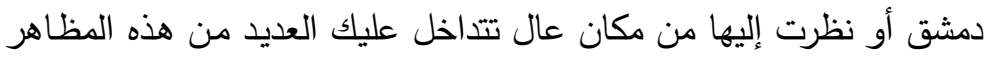

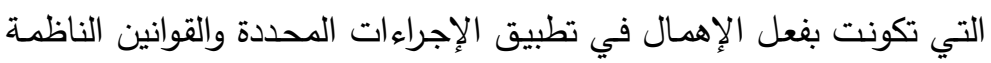

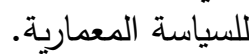
وتعتبر اطباق التقاط الاشـارات الفضـائية وخزانـات المياه المنتشرة بثكل

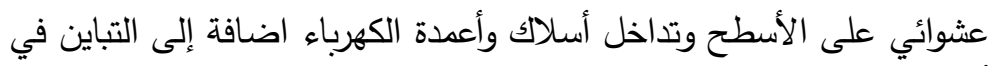

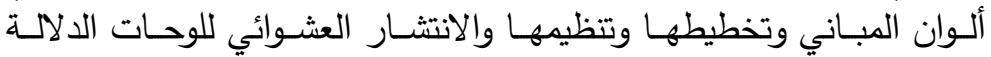

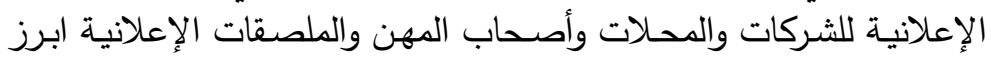

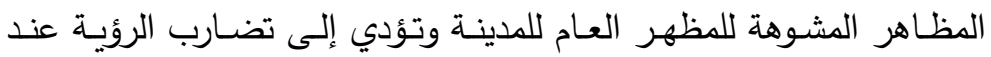
الزائر فيما يتعلق بعراقتها وأصالتها وبشكل مساير لتقدمها في مجالات التطودئ التطور المعماري والاقتصادي والسياحي. 
إن التشوه البصري في المدينة واحياؤها القديمة يحدث تأثيرا مغايرا للصورة التي ترتسم لدى الكثيرين عن المدينة وتاريخها وأهميتها

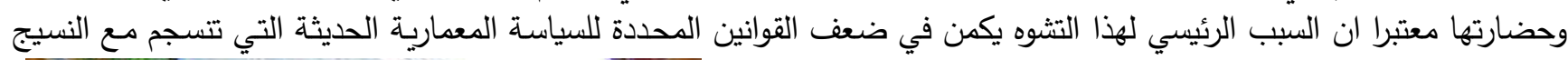

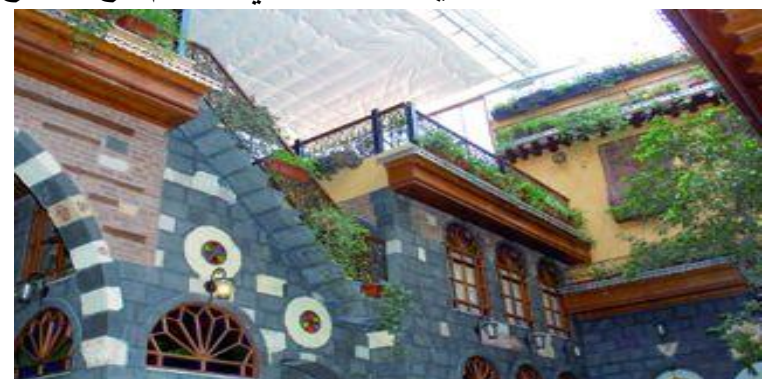

(8) صورة توضح عملية الترميم لاحد المباني التاريخية

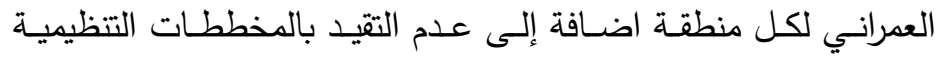
الموضوعة لهذه الغاية.

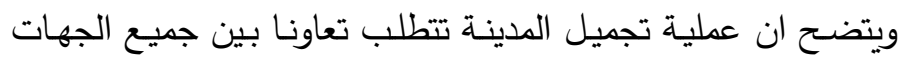

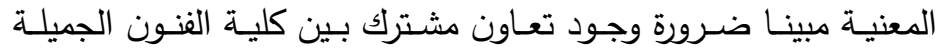

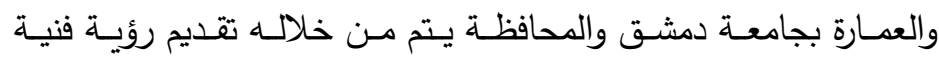

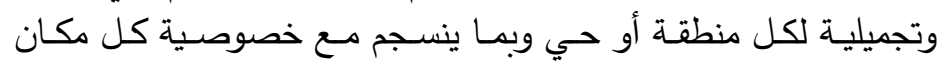

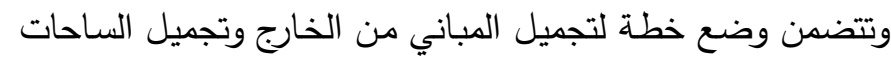

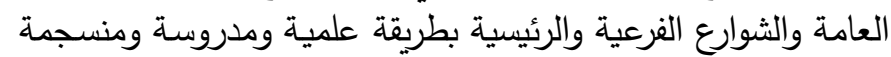
مع طبيعة كل منطقة.

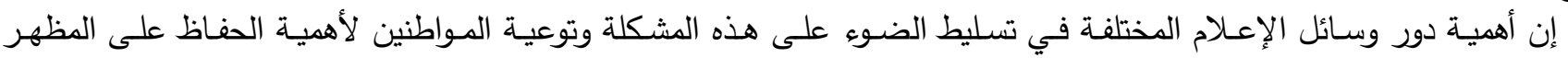

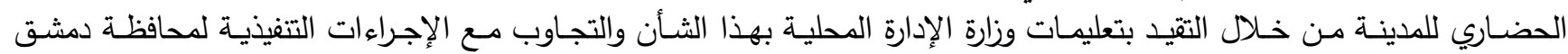

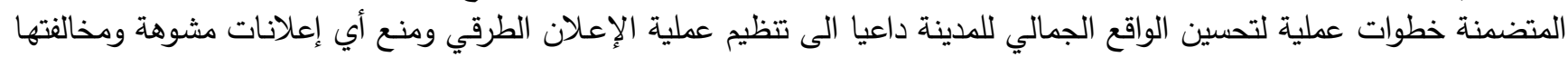

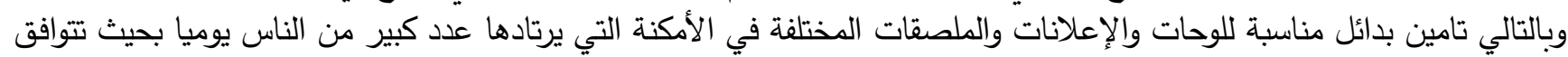

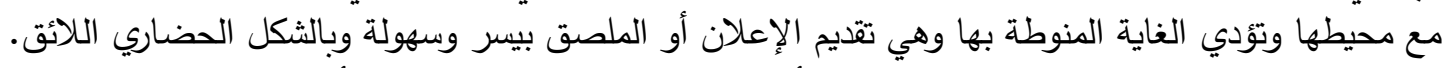

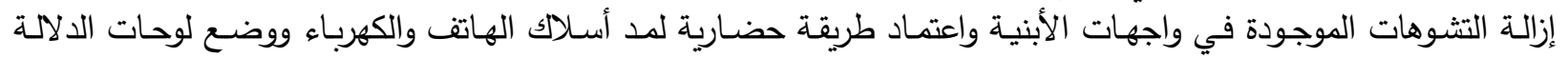

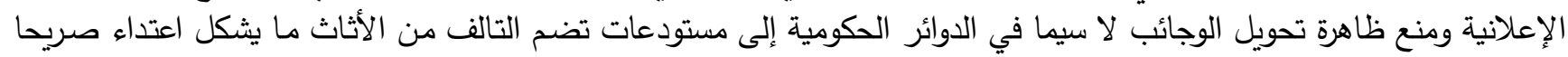
على الذوق العام.

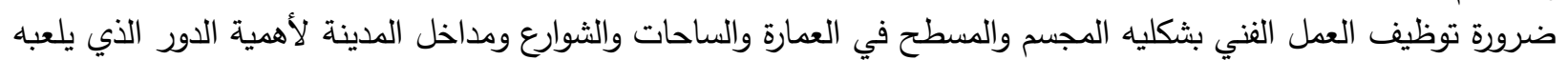

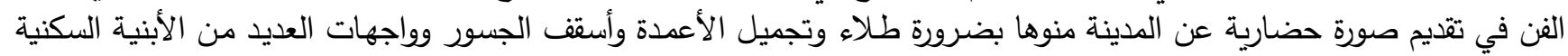
والخدمية التي فقدت بريقها بفعل العوامل الجوية.

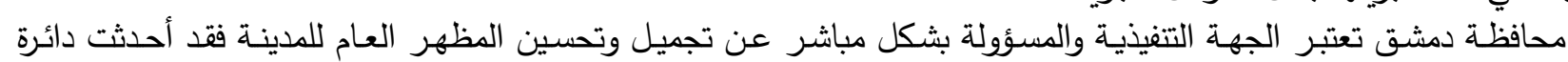

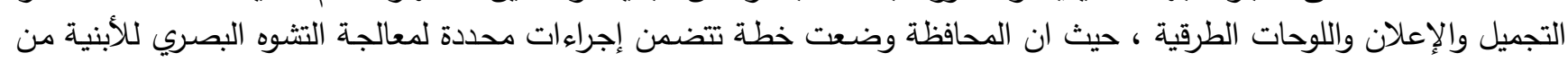

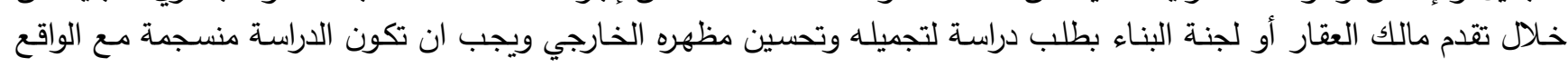

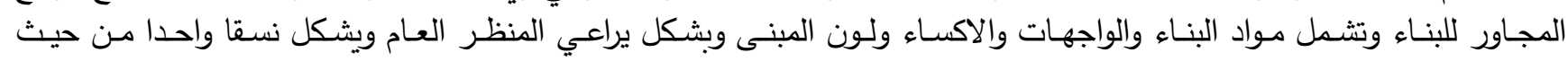
المواصفات الخارجية بالتكامل مع الأبنية المحيطة.

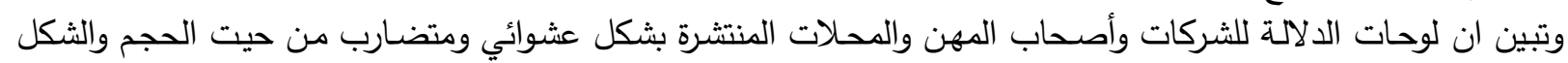

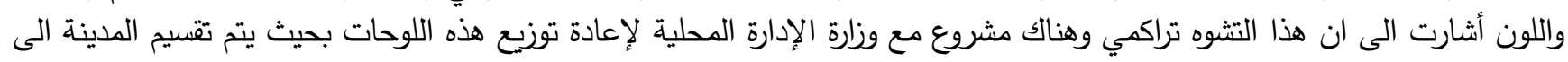

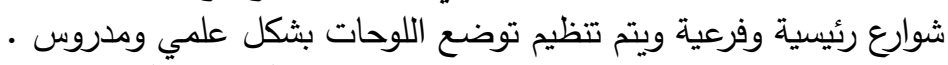

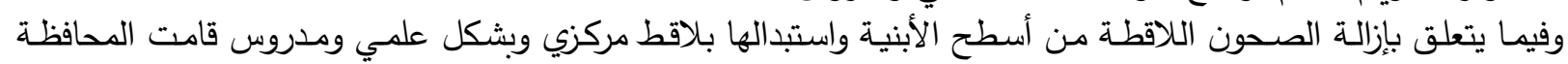

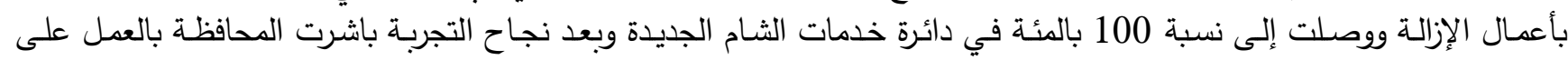

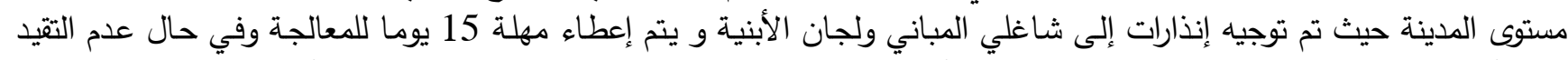

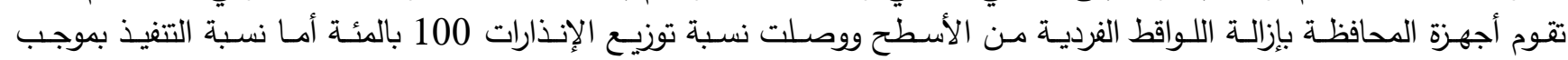

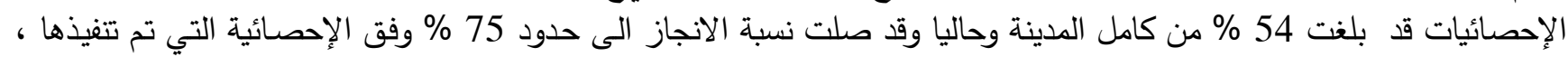

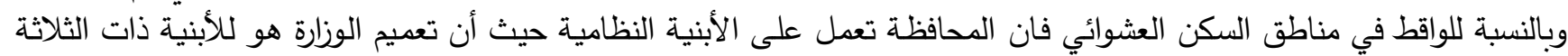

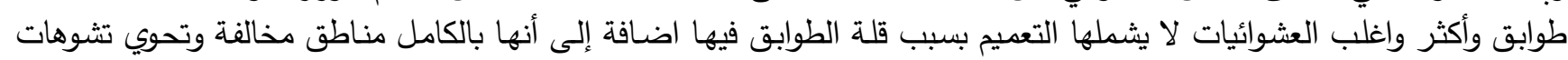

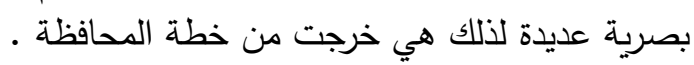

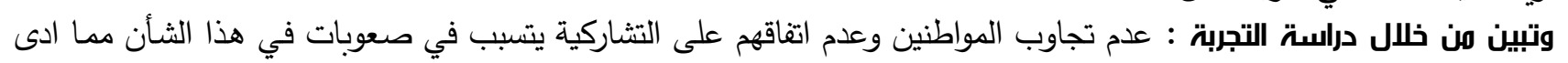

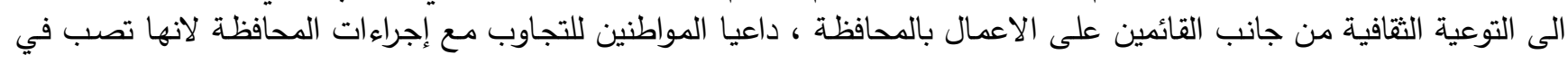

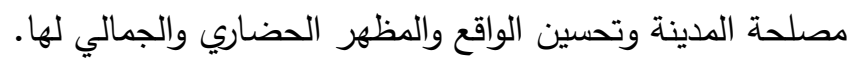

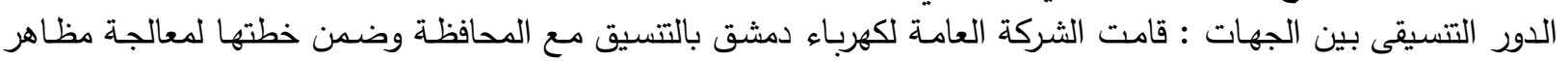

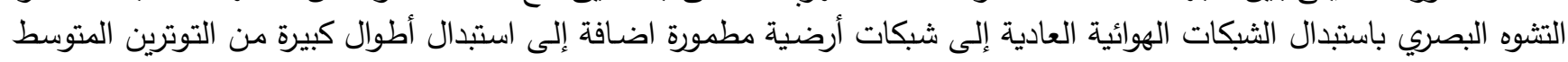

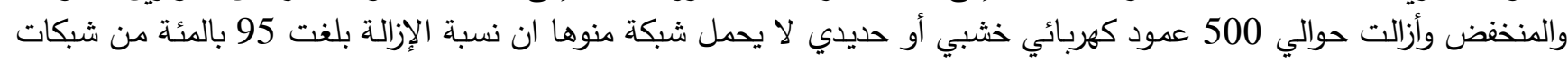

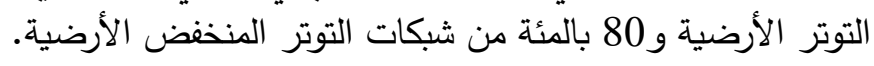


كما تقوم الشركة تقوم بإزالة مراكز التحويل الكهربائية المكثوفة والتعويض عنها بمراكز تحويل مطمورة ونصف مطمورة ما يحد

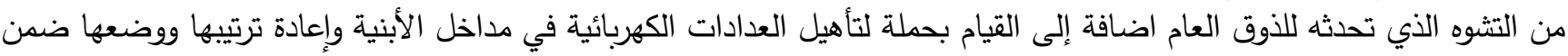

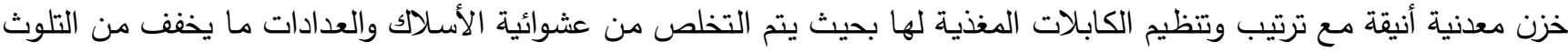

النتائي المستخلمة من التجارب :

تم دراسة عدة تجارب لمدن عربية تبنت فكرة طرح مشروعات لتحسين المشهد الحضرى للمدينة بما فيها الاحياء القديمة

\begin{tabular}{|c|c|c|c|}
\hline ممول التجربة & الاروب المستفادة & القائمين عليها & اسم التجربة \\
\hline المقدسة المـاتة العاصــمة & 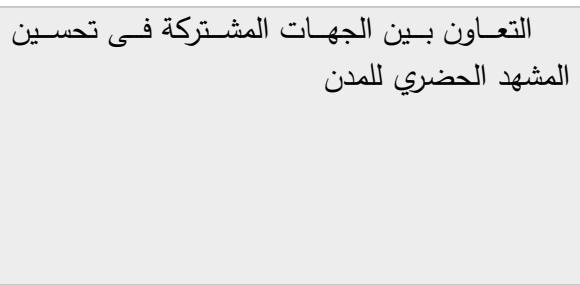 & 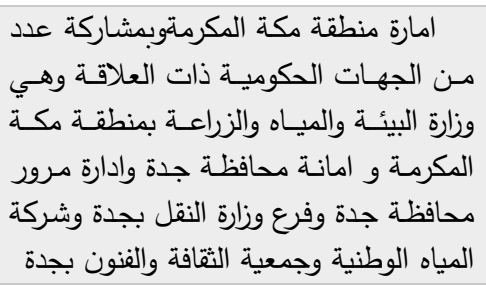 & مكة المكرمة \\
\hline 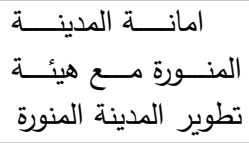 & تحديد عناصر تلوث المشهد الحضري & 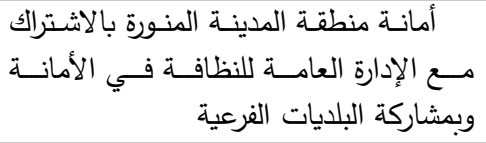 & المنورة تجربـة المدينــة \\
\hline الشرقية امانــــة المنطقــــة & 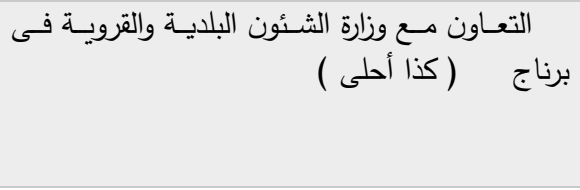 & 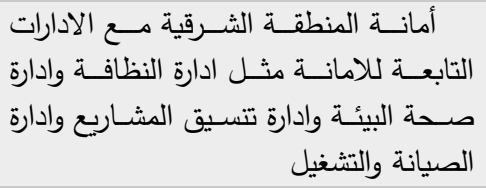 & 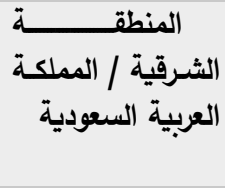 \\
\hline محافظة دمشق & 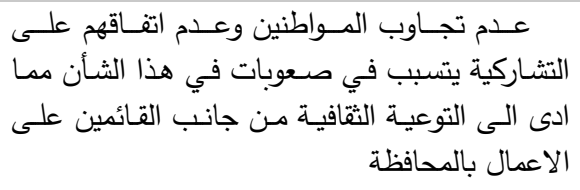 & 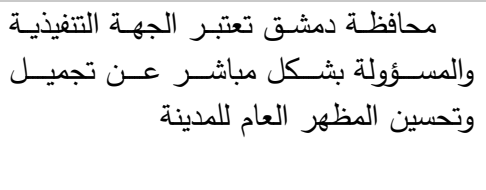 & سوريا \\
\hline
\end{tabular}

:

يستخلص البحث قائمة ببعض مظاهر التلوث البصري من خلال التجارب التى تم دراستها من خلال البحث والتجارب التى تم

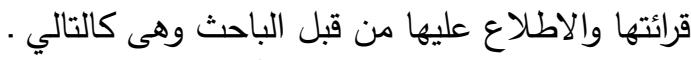

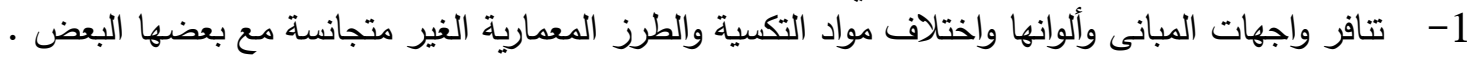

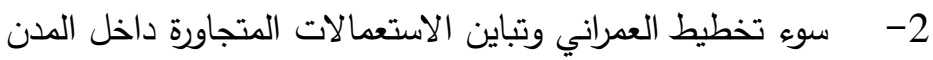

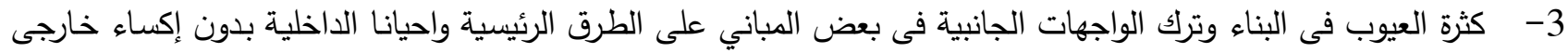

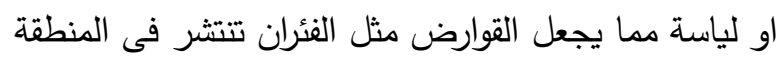

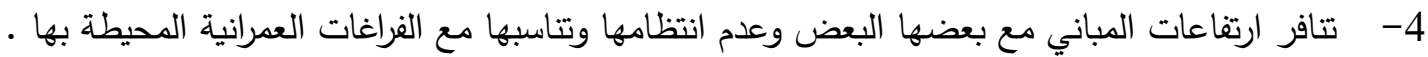

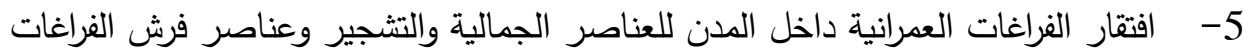

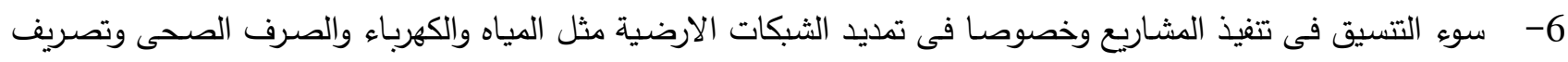

7- - رمى النفايات ومخلفات البناء والهدم المستمر فى الاراضى الفضاء وشوارع الاحياء داخل المدن 8- استغلال الارصفة فى عرض بعض المنتجات

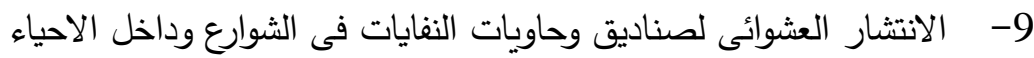

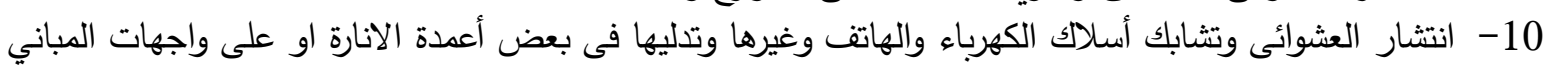

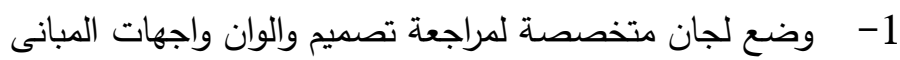
2 - - تمل صناديق فرز النفايات بتصميم حضرى وقريب من الاماكن العامة

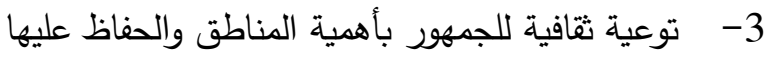

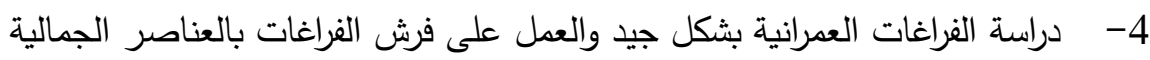
5- تحديد ارتفاعات المبانى بقوانين صارمة داخل المناطق والاحياء القديمة 
[1] - Kevin Lynch and Malcolm Rivkin: A Walk Around the Block. In Environmental

Psychology, People and Their Environment by Harold Proshansky, William Ittelson and Leanne Rivlin. Holt, Rinehart and Winston, New York, Chicago, San Francisco. 1976. p. 363. [2]د. ناجى بلر إبراهيم في د. غريب محمد سيد احمد ود. نادية عمر ود. ناجى بلر ابراهيم ود. حمدى على احمد ود. السيد

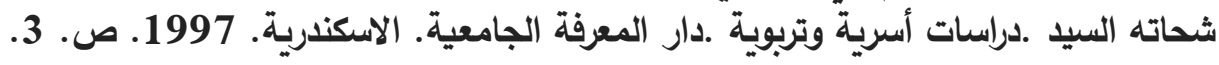

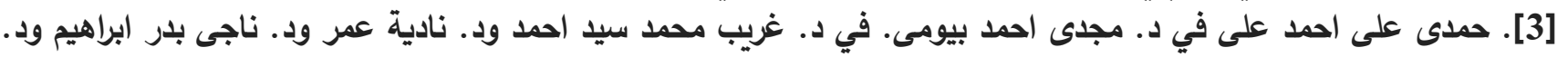

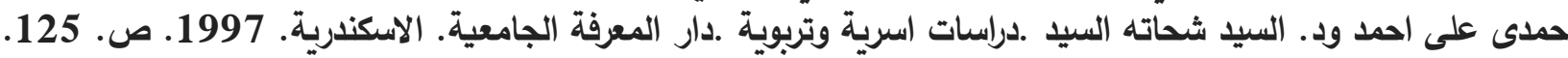

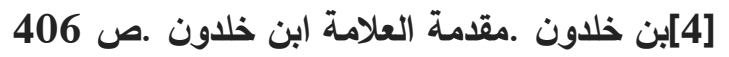

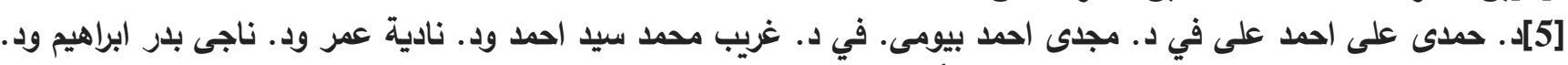

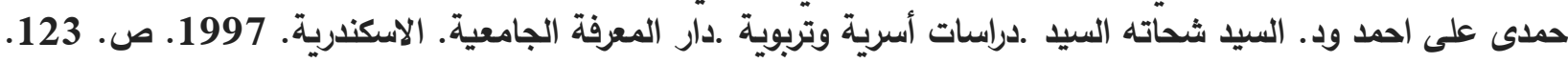

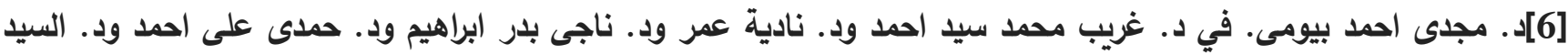

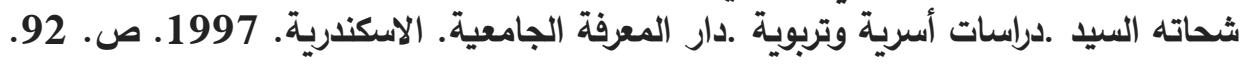

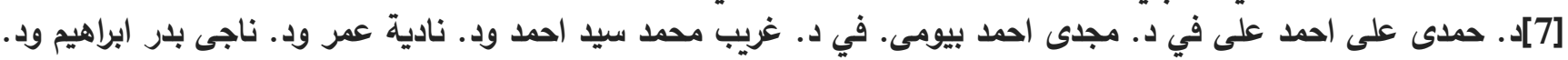

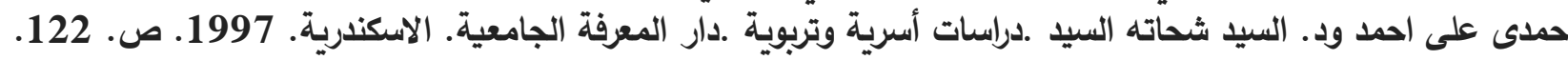

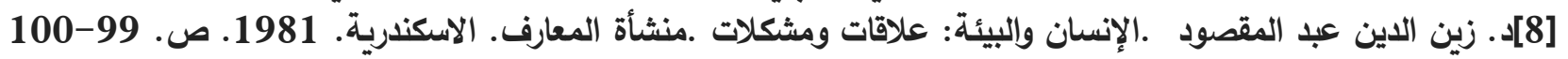
[9][السيد عبد العاطى السيد .الإنسان والبيئة .دار المعرفة الجامعية. 10د. غريب محمد سيد احمد وآخرون .دراسات أسرية وبيئية .دار المعرفة الجامعية. 1996.

[11]د. منى ابراهيم حامد الفرنوانى .تلوث البيئة الريفية: دراسة لبعض آثار تغير أيكولوجية القرية المصرية .في البيئة والمجتمع:

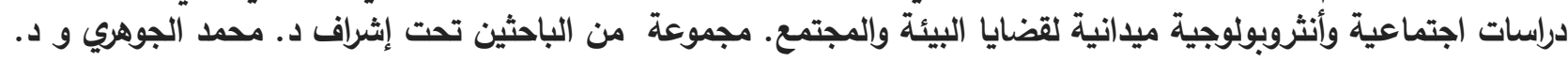

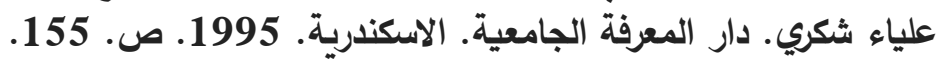

[12] مجدى محمد رضوان و م. محمد عبد السميع عيد :تأثير النمو الحضري على البيئة العمرانية للمدن بالدول النامية .المؤتمر الأول للبحوث الهندسية محل رضوان 1991.

[13]د. منى ابراهيم حامد الفرنوانى .تلوث البيئة الريفية: دراسة لبعض آثار تغير ايكولوجية القرية المصرية .في البيئة والمجتمع:

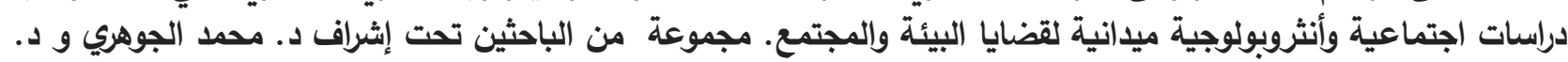

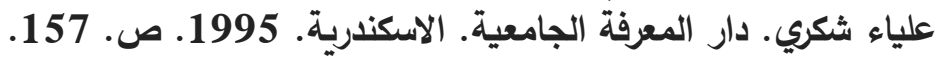

[14]. هناء الجوهري .متغيرات البيئة الفيزيقية والاجتماعية لنوعية الحياة .في البيئة والمجتمع: دراسات اجتماعية وأنثروبولوجية

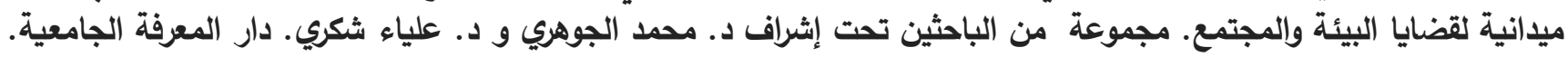
الاسكندرية. 1995.

[15]. مجدى محمد رضوان و م. محمد عبد السميع عيد :تأثير النمو الحضري على البيئة العمرانية للمدن بالدول النامية . المؤتمر الأول للبحوث الهندية 1591.

[16]د. إسماعيل عامر .أسباب مصادر التلوث وأثره على العمران .جمعية المهندين المصرية - مارس 1989. [17]. احسان زكى دردير .دراسة تحليلية لتحسين مسار عمارتنا المعاصرة للارتقاء بالقاهرة الإسلامية .ورقة مقدمة إلى المؤتمر

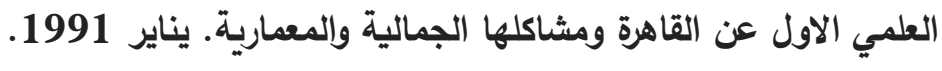

[18]د. ماجدة متولى .ندوة التلوث البصري .جمعية المهندسين المصريين. القاهرة. 1986.

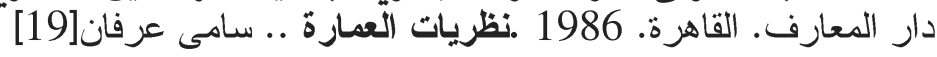

